\title{
Liquid Anion Exchange Chromatographic Extraction and Separation of Platinum(IV) with n-Octylaniline as a Metallurgical Reagent: Analysis of Real Samples
}

\author{
Ashwini P. Gaikwad, Ganesh S. Kamble, Sanjay S. Kolekar, and Mansing A. Anuse \\ Analytical Chemistry Laboratory, Department of Chemistry, Shivaji University, Kolhapur, Maharashtra 416 004, India \\ Correspondence should be addressed to Mansing A. Anuse; mansinganuse@yahoo.co.in
}

Received 3 May 2013; Revised 21 July 2013; Accepted 22 July 2013

Academic Editor: Concha Gimeno

Copyright (C) 2013 Ashwini P. Gaikwad et al. This is an open access article distributed under the Creative Commons Attribution License, which permits unrestricted use, distribution, and reproduction in any medium, provided the original work is properly cited.

A simple and selective method was developed for the determination of platinum(IV) with n-octylaniline in toluene. In present study, the use of n-octylaniline in toluene for the extraction of platinum(IV) from ascorbate media was carried out. The effect of various parameters, such as $\mathrm{pH}$, equilibrium time, extractant concentration, and organic solvent on the extraction has been discussed. The back extraction of platinum(IV) has been performed. On the basis of slope analysis, the composition of the extracted species was determined as $\left[\mathrm{RR}^{\prime} \mathrm{NH}_{2}{ }^{+} \mathrm{Pt}(\text { Succinate })_{2}{ }^{-}\right]_{(\mathrm{org})}$. The interfering effects of various cations and anions were also studied, and the selectivity of the method is enhanced by using suitable masking agents. The proposed method is rapid, reproducible and successfully applied for the determination of platinum(IV) in binary and synthetic mixtures. The separation of pt(IV) from other associated metals has been studied. Comparison of the results with those obtained using an atomic absorption spectrophotometer also tested the validity of the method.

\section{Introduction}

The platinum group of metals (PGMs: Pt, Pd, Rh, Ir, Ru, and Os) are extremely scarce in comparison to the other precious metals due to not only to their low natural abundance but also to the complexity of the processes required for their extraction and refinement. In comparison with other precious metals ( $\mathrm{Au}$ and $\mathrm{Ag}$ ), these platinum group metals (PGMs) are extensively in the use as catalysts in the automobile, chemical, and petroleum industries. In automobiles, $\mathrm{Pt}$ and $\mathrm{Pd}$ are used as catalytic converter to reduce harmful emissions. In the petroleum cracking process, the catalyst containing Pt and Pd helps to break oil molecules into smaller organic molecules [1]. Besides, PGMs are also used as conductors in the electrical and electronic industries, in extrusion devices, in dental and medical prostheses, and in jewelry [2]. Due to their special chemical and physical properties, the substitution of PGMs by other metals is difficult [3]. Since the need for PGMs is increasing, recovery of PGMs from spent catalysts is very important.
Economically, the precious metals have been historically important as currency and remain important as investment commodities. Gold, silver, platinum, and palladium are internationally recognized as forms of currency under ISO 4217 [4]. Technological and analytical platinum-containing solutions have diverse ratios of the concentrations of platinum and associate precious, base, and ferrous metals, acidities, and salt backgrounds. This diversity arises from the complex and variable composition of raw materials. Naturally, selective extraction and separation of platinum (as well as platinumgroup metals and gold) from associate metals become a problem in subsequent hydrometallurgical processing of these complex solutions. Technological and analytical platinumcontaining solutions have diverse ratios of the concentrations of platinum and associate precious, base, and ferrous metals, acidities, and salt backgrounds. This diversity arises from the complex and variable composition of raw materials. A major problem in developing extraction methods for the platinum group metal ions, especially for platinum(II), arises from slow extraction rates. Heating the solution $[5,6]$ and/or 
the use of tin(II) chloride as a catalyst [7-9] have been commonly used to accelerate the extraction. Among the PGMs separations, $\mathrm{Pd}(\mathrm{II}) / \mathrm{Pt}(\mathrm{IV})$ mutual separation has been extensively investigated due to its difficulty based on their chemically similar properties. The large difference in the extraction rate between $\mathrm{Pd}(\mathrm{II})$, and $\mathrm{Pt}(\mathrm{IV})$ from aqueous chloride solutions, which is attributable to the extremely inert properties of $\mathrm{Pt}(\mathrm{IV})$ compared with $\mathrm{Pd}(\mathrm{II})$ is usually applied to their separation [10].

High molecular weight amines (HMWAs) find many applications in the solvent extraction of platinum(IV) from weak organic acid and mineral acid medium. These are p-octylaniline [11], N-octyl-, N,N-dioctyl aniline and N,N,Ntrioctyl anilinium O,O-di(isopropyl)dithiophosphates [12], N-n-octylaniline [13], Trioctylamine [14-19], alamine 336 [20-23], alamine 300 [24], and quaternary amine base salts [25-32]. However, these amines show emulsion formation, narrow extraction $\mathrm{pH}$ range. Extraction of platinum(II) by bisacylated diethylenetriamine [33] from hydrochloric acid solution was studied. Platinum can be separated by this method from nonnoble metals. Extraction of platinum(II) was carried out from acidic solution at $\mathrm{pH}$ range 1-4 by using two hydrophobic analogs of $\mathrm{N}, \mathrm{N}, \mathrm{N}^{\prime}, \mathrm{N}^{\prime}$-tetrakis[2-pyridyl-methyl]-1,2-ethyl-enediamine (TPEN). N,N, $\mathrm{N}^{\prime}, \mathrm{N}^{\prime}$-Tetrakis[4-(2-butyloxy)-2-pyridyl-methyl]-1,2-ethylenediamine (TBPEN) and $\mathrm{N}, \mathrm{N}, \mathrm{N}^{\prime}, \mathrm{N}^{\prime}$-tetrakis(2-quinolinylmethyl)-1,2ethylenediamine (TQEN) [34] have shown enhanced solvent extraction performance in more acidic media than TPEN. The platinum ion was extracted in the deactivated catalyst for the hydrochlorination reaction of ethyne by acidic thiourea [35] solution. $\mathrm{N}^{\prime} \mathrm{N}^{\prime}$-dihexyl and phenyl and $\mathrm{N}^{\prime}$-hexyl and phenyl derivatives of $\mathrm{N}$-benzoyl thiourea [36] are very good reagents for $\mathrm{pH}$ selective extractions, especially for platinum. Important interfering elements in the extraction of platinum as $\mathrm{Cu}, \mathrm{Fe}, \mathrm{Ni}$. Solvent extraction of platinum(IV) by $\mathrm{N}, \mathrm{N}$-dihexyl- $\mathrm{N}^{\prime}$-benzoyl-thiourea [37] in toluene is substantially accelerated in the presence of stannous chloride. The extraction behavior of platinum(II) is not affected by the treatment of stannous chloride. Liquid-liquid extraction of the platinum(IV) with pure synthesized N,N-diethyl-N'-benzoylthiourea (DEBT) [38] was carried out by optimizing the concentration of acid, mole ratio of metal to chelating agent, temperature, and extraction time. The extraction behavior of platinum(II) with 1,3-dimethyl-2-thiourea (DMTU) [39] from a chloride solution was studied. Bromocresol green ion as a counter anion and 1,2-dichloroethane as an extraction solvent were used. Platinum(II) was quantitatively extracted into 1,2-dichloroethane within $15 \mathrm{~min}$. The interferences of $\mathrm{Mn}$ (II), $\mathrm{Cu}(\mathrm{II})$, $\mathrm{Zn}(\mathrm{II}), \mathrm{Pd}(\mathrm{II}), \mathrm{Ag}(\mathrm{I})$, and $\mathrm{Cd}(\mathrm{II})$ were removed by adding suitable masking agents. The extractant nonylthiourea (NTH) $[40,41]$ in chloroform has been investigated for the extraction of platinum(IV) from chloride solution at ionic strength 4.0 M. It has been found that chloride concentration has a negative effect on the extraction while proton concentration has no effect. N-Phenyl- $\mathrm{N}^{\prime}$-[o-(2-ethylhexylthio)phenyl]thiourea (PEPT) [42] which contained donor atoms of sulfur and nitrogen was synthesized to
TABLE 1: Extraction behaviour of platinum(IV) as a function of diluents. $(\mathrm{Pt}(\mathrm{IV})=150 \mu \mathrm{g}, \mathrm{Aq}: \mathrm{Org}=2.5: 1, \mathrm{pH}=0.50$, ascorbic acid $=0.01 \mathrm{M}$, equilibrium time $=3 \mathrm{~min}$, and strippant $=$ water $(2 \times 10 \mathrm{~mL}))$.

\begin{tabular}{lccc}
\hline Solvent & $\begin{array}{c}\text { Dielectric } \\
\text { constant, }(\varepsilon)\end{array}$ & $\begin{array}{c}\text { Percentage } \\
\text { extraction, }(\% E)\end{array}$ & $\begin{array}{c}\text { Distribution } \\
\text { ratio, }(D)\end{array}$ \\
\hline Benzene & 2.27 & 100 & $\infty$ \\
Xylene & 2.30 & 100 & $\infty$ \\
Toluene $^{*}$ & 2.38 & 100 & $\infty$ \\
Chloroform & 4.80 & 23.8 & 0.78 \\
Methyl isobutyl & 13.10 & 60.8 & 3.87 \\
ketone & 17.80 & No extraction & - \\
$n$-Butanol & 13.90 & No extraction & - \\
Amyl alcohol & 13.90 & No extraction & - \\
Amyl acetate & 10.50 & No extraction & - \\
1,2-Dichloroethane &
\end{tabular}

${ }^{*}$ Recommended for general extraction procedure.

develop a selective extractant for platinum(IV) from base metals from acidic chloride media at $303 \mathrm{~K}$.

In present study, the use of n-octylaniline in toluene for the extraction of platinum(IV) from ascorbate media was carried out. The extraction system is studied as a function of $\mathrm{pH}$, extractant concentration, diluents, and equilibrium period. The conventional slope analysis method was employed for analysis of species formed in organic phase. The method is free from large number of interferences due to various foreign ions.

The review of literature for comparison of liquid-liquid extractive separation of platinum(IV) is given in Table 1 .

\section{Experimental}

2.1. Instruments. An Elico digital spectrophotometer model 12 Chemito 215D with $1 \mathrm{~cm}$ quartz cells was used for absorbance measurements, and $\mathrm{pH}$ measurements were carried out using an Elico digital pH-meter model LI-127. All weighing operations were carried out by using Tapson's analytical single pan balance model $200 \mathrm{~T}$ having $0.001 \mathrm{~g}$ accuracy.

2.2. Chemicals and Solutions. Standard solution of platinum(IV) was prepared by dissolving $1 \mathrm{~g}$ of hydrogen hexachloroplatinate (IV) hydrate, $\mathrm{H}_{2} \mathrm{PtCl}_{6} \cdot \mathrm{H}_{2} \mathrm{O}$ (Johnson and Matthey, UK), in $1 \mathrm{M}$ hydrochloric acid and was standardized gravimetrically [43]. A working solution $(100 \mu \mathrm{g} / \mathrm{mL})$ was made there by appropriate dilution. All chemicals used were of AR grade. Double distilled water was used throughout.

2.2.1. $\mathrm{n}$-Octylaniline, $0.1 \mathrm{~mol} \mathrm{~L}^{-1}$. The extractant n-octylaniline was prepared by the method of Pohlandt's [44], and its $0.1 \mathrm{M}$ solution was prepared in toluene. All other solutions were prepared from AR grade reagents, and aqueous solutions were prepared using water. 
Standard solutions of diverse ions were prepared by dissolving AR grade reagents in water or dil $\mathrm{HCl}$. All the organic solvents were used after double distillation. All chemicals used were of AR grade.

2.3. General Extraction and Determination Procedure for Platinum(IV). An aliquot of $150 \mu \mathrm{g}$ platinum(IV) solution was mixed with a sufficient quantity of ascorbic acid to make its concentration $0.01 \mathrm{M}$ in a total volume of $25 \mathrm{~mL}$ of the solution. The $\mathrm{pH}$ of the aqueous solution was adjusted to 0.50 by dilute sodium hydroxide and hydrochloric acid solution. The solution was then transferred to a $125 \mathrm{~mL}$ separating funnel and shaken with $10 \mathrm{~mL}$ of $0.1 \mathrm{M}$ n-octylaniline in toluene for $3 \mathrm{~min}$. After separating the two phases, the aqueous phase was discarded and the organic phase was stripped with two $10 \mathrm{~mL}$ portion of water solution. After being stripped with water, all the $150 \mu$ g platinum(IV) has come into the aqueous phase. So after stripping with water, in organic phase have no any platinum(IV), which is tested by AAS.

The stripped aqueous phase was evaporated to moist dryness and extracted into water.

A percentage extraction $(\% E)$ and metal distribution ratio $(D)$ were calculated according to (1) and (2), respectively:

$$
\begin{gathered}
\% E=\frac{[M]_{\text {org. }}}{[M]_{\text {aq.,init. }}} \times 100, \\
D=\frac{[M]_{\text {org. }}}{[M]_{\text {aq. }}}
\end{gathered}
$$

where $[M]_{\mathrm{aq}, \text {,init. }}$ represents the initial concentration of metal ion in the aqueous phase. $[M]_{\mathrm{aq}}$ and $[M]_{\text {org. }}$ are the total concentrations of metal ion in the aqueous and organic phases after equilibrium, respectively.

2.3.1. Estimation Procedure for Platinum(IV). The resulting aqueous phase was mixed with $5 \mathrm{~mL}$ of concentrated hydrochloric acid in $25 \mathrm{~mL}$ volumetric flask and $10 \mathrm{~mL}$ of $25 \%(\mathrm{~W} / \mathrm{V})$ stannous chloride in concentrated hydrochloric acid, and the solution was diluted to mark with water. The absorbance of the resulted solution was measured at $405 \mathrm{~nm}$ [45]. The concentration of platinum(IV) was found from calibration curve.

\section{Results and Discussion}

3.1. Extraction as a Function of $p H$. The extraction studies of platinum(IV) were performed at fixed concentration of $0.01 \mathrm{M}$ ascorbic acid and between $\mathrm{pH} 0.10$ and 5.0 with a $0.1 \mathrm{M}$ solution of $\mathrm{n}$-octylaniline in toluene. The $\mathrm{pH}$ range observed for the quantitative extraction was $0.50-1.0$ with noctylaniline. Hence the extraction of platinum(IV) was carried out at $\mathrm{pH} 0.50$ for all extraction experiments (Figure 1).

3.2. Effect of Weak Organic Acid Concentration. The extraction of platinum(IV) was examined at $\mathrm{pH} 0.50$ with $0.1 \mathrm{M} \mathrm{n}$ octylaniline in toluene in presence of varying concentrations from $0.001-0.1 \mathrm{M}$ of ascorbic acid. The extraction of ionpair complex of platinum(IV) was found to be quantitative

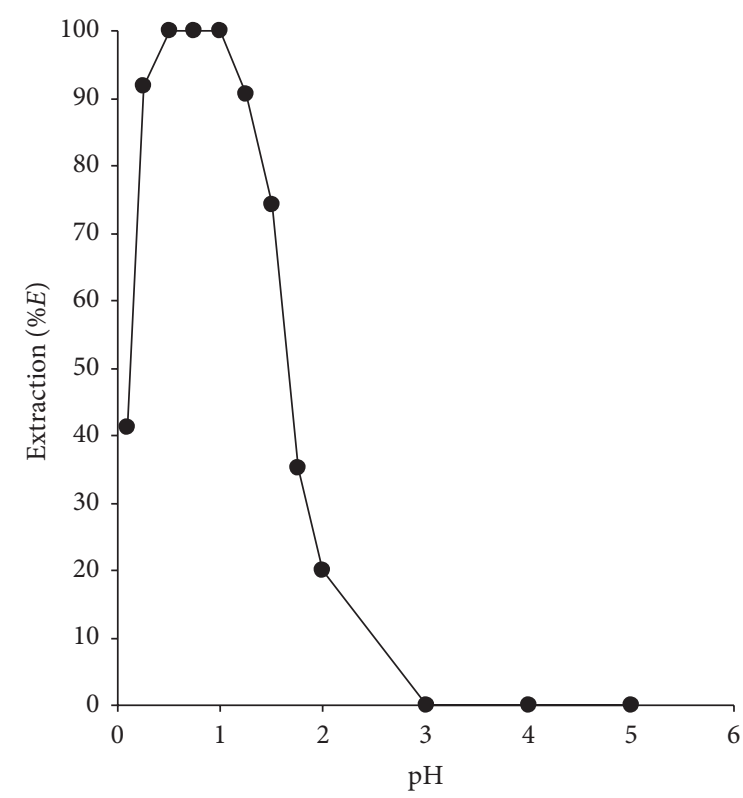

FIGURE 1: Plot of $\mathrm{pH}$ versus percentage extraction of platinum(IV) $(150 \mu \mathrm{g} / \mathrm{mL})$ from ascorbic acid medium $(0.01 \mathrm{M})$ by using $\mathrm{n}$ octylaniline $(0.1 \mathrm{M})$ as an extractant in toluene with 3 min shaking time.

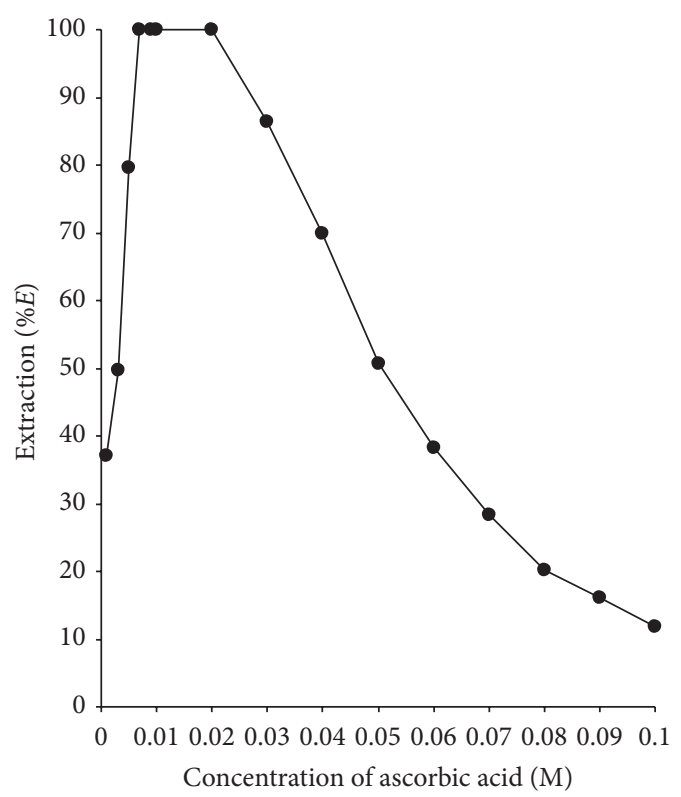

FIGURE 2: Extraction of platinum(IV) $(150 \mu \mathrm{g})$ with $0.1 \mathrm{M} \mathrm{n}$ octylaniline at $\mathrm{pH} 0.50$ as a function of weak acid concentration.

in the range of $0.007-0.02 \mathrm{M}$ ascorbic acid. Hence, $0.01 \mathrm{M}$ concentration of ascorbic acid was used for further studies while zero extraction of platinum(IV) was found to be in sodium salicylate, malonate, and succinate (Figure 2).

3.3. Effect of n-Octylaniline Concentration. Extraction of platinum(IV) was carried out with various concentrations of n-octylaniline in toluene. To optimize the extraction 


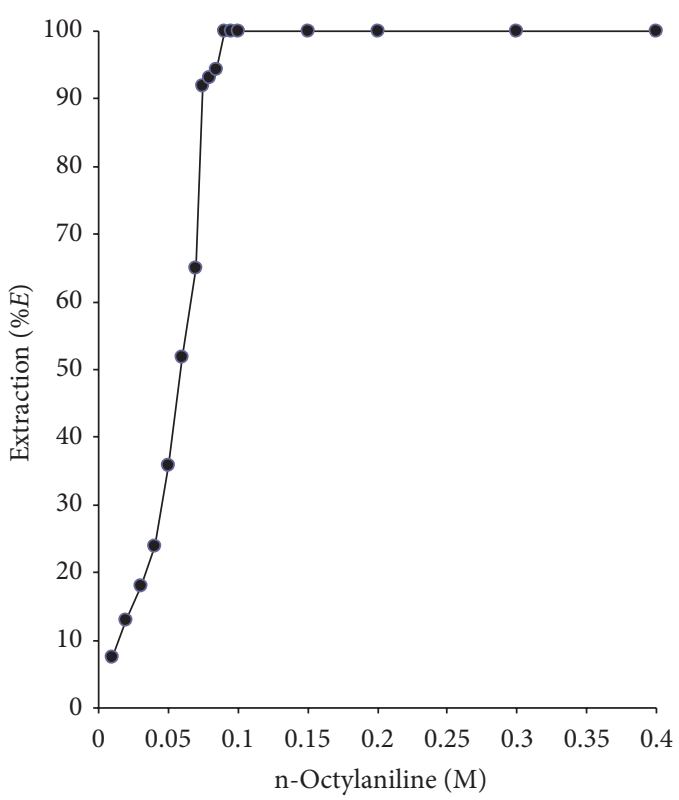

Figure 3: Extraction of platinum(IV) $(150 \mu \mathrm{g} / \mathrm{mL})$ at $\mathrm{pH} 0.50$ from $0.01 \mathrm{M}$ ascorbic acid medium as a function of $\mathrm{n}$-octylaniline concentration.

condition, other parameters like $\mathrm{pH}$, period of equilibration, and diluent were kept constant. The extraction was found to be increased with increasing reagent concentration. The extraction of platinum(IV) was quantitative in the range from $0.09 \mathrm{M}$ to $0.4 \mathrm{M}$ of $\mathrm{n}$-octylaniline in toluene. However, $10 \mathrm{~mL}$ of $0.1 \mathrm{M}$-octylaniline in toluene was recommended for general extraction procedure (Figure 3).

3.4. Effect of Diluents. The studies were then performed to find out the most suitable solvent for the extraction of the ion-pair complex of platinum(IV). It was found that a $0.1 \mathrm{M}$ solution of n-octylaniline in benzene, toluene, and xylene provides quantitative extraction of platinum(IV). The extraction of platinum(IV) was incomplete if n-octylaniline is dissolved in chloroform (23.8\%), methyl isobutyl ketone (60.8\%) while no extraction in amyl alcohol, 1,2-dichloroethane, $n$ butyl alcohol, and amyl acetate (Table 1). On safety ground, toluene was preferred to other solvents.

3.5. Effect of Equilibration Time. The extraction of platinum(IV) was studied for various time intervals in the range of 1-20 min with $0.1 \mathrm{M} \mathrm{n}$-octylaniline. It was observed that, under the optimized experimental conditions, a minimum 2 min time interval was required for attaining equilibrium in the sense to extract platinum(IV) quantitatively. But with prolonged shaking over $10 \mathrm{~min}$ there was decrease in the percentage extraction of platinum(IV) due to the dissociation of ion-pair complex. Hence, in all further studies, both the phases were equilibrated for $3 \mathrm{~min}$.

3.6. Effect of Stripping Agent. Platinum(IV) from organic phase was stripped with the two $10 \mathrm{~mL}$ portions of various stripping agents at different concentrations of mineral acids,
TABLE 2: Extraction behavior of platinum(IV) as a function of stripping agents. $(\mathrm{Pt}(\mathrm{IV})=150 \mu \mathrm{g}, \mathrm{Aq}: \mathrm{Org}=2.5: 1, \mathrm{pH}=0.50$, ascorbic acid $=0.01 \mathrm{M}$, equilibrium time $=3 \mathrm{~min}$, and $\mathrm{n}$-octylaniline $=0.1 \mathrm{M}$ in toluene).

\begin{tabular}{lcc}
\hline Strippant & mol/L/pH & Percentage extraction, $(\% E)$ \\
\hline Ammonia & $1-10$ & 53.4 \\
$\mathrm{HCl}$ & $1-3$ & 16.7 \\
$\mathrm{H}_{2} \mathrm{SO}_{4}$ & $1-3$ & 20.7 \\
$\mathrm{HNO}_{3}$ & $1-3$ & 31.9 \\
$\mathrm{HBr}$ & $1-3$ & 12.3 \\
Water* & - & 100 \\
$\mathrm{NaCl}$ & $1-5 \%$ & 65.2 \\
Ammonia buffer & pH-10 & No stripping \\
\hline
\end{tabular}

${ }^{*}$ Recommended for general extraction procedure.

buffer solutions, and some bases. Platinum(IV) was quantitatively stripped with water (Table 2). However, percentage recovery of platinum(IV) from organic phase was found to be incomplete with strippants ammonia, hydrochloric acid, nitric acid, sulphuric acid, sodium chloride, and hydrobromic acid and no stripping in ammonia buffer ( $\mathrm{pH} 10)$. In recommended procedure, two $10 \mathrm{~mL}$ portions of water were used for the complete stripping of loaded organic phase.

3.7. Effect of Aqueous to Organic Volume Ratio. The extraction of platinum(IV) was carried out in different aqueous volumes in the range $100-10 \mathrm{~mL}$ from $0.01 \mathrm{M}$ ascorbic acid medium with $10 \mathrm{~mL} 0.1 \mathrm{M} \mathrm{n}$-octylaniline in toluene (Table 3). There was observed quantitative extraction of platinum(IV) when phase ratio A/O maintained from $1: 1$ to $4: 1$. Therefore, in the recommended procedure, the phase ratio $2.5: 1$ was maintained through the all experimental study.

3.8. Metal Loading Capacity of Extractant. The influence of the initial platinum(IV) concentration $50-2500 \mu \mathrm{g}$ on the extraction by $0.1 \mathrm{M}$-octylaniline in toluene was studied. It was observed that varying the initial platinum(IV) concentration in the range of 50-1500 $\mu \mathrm{g}$ has no significant influence on platinum(IV) extraction with the $10 \mathrm{~mL}$ of $0.1 \mathrm{M}$ extractant (Table 4). The maximum loading capacity of $10 \mathrm{~mL} 0.1 \mathrm{M}$ solution of n-octylaniline in toluene was found to be $1500 \mu \mathrm{g}$ platinum(IV).

3.9. Nature of Extracted Species. Attempts were made to ascertain the nature of extracted species of platinum(IV) with the extractant using conventional slope analysis method. The distribution ratio of platinum(IV) evaluated at different concentration in molar of ascorbic acid was used at fixed noctylaniline concentration at $\mathrm{pH} 1.25$ and $\mathrm{pH} 1.50$. A graph of $\log D_{[\mathrm{Pt}(\mathrm{IV})]}$ versus $\log C_{\text {[ascorbate] }}$ gave a slopes of 2.8 and 3.0, respectively (Figure 4 ). Similarly, a plot of $\log D_{[\mathrm{Pt}(\mathrm{IV})]}$ versus $\log C_{\text {[n-octylaniline] }}$ concentrations at a fixed $\mathrm{pH} 1.25$ and $\mathrm{pH} 1.50$ with $0.1 \mathrm{M}$ ascorbate gave slopes of 1.3 and 1.2, respectively (Figure 5). This indicates a mole ratio of platinum(IV) to ascorbic acid as $1: 3$ and that of n-octylaniline as $1: 1$. Thus, the extracted species was calculated to be an ion 


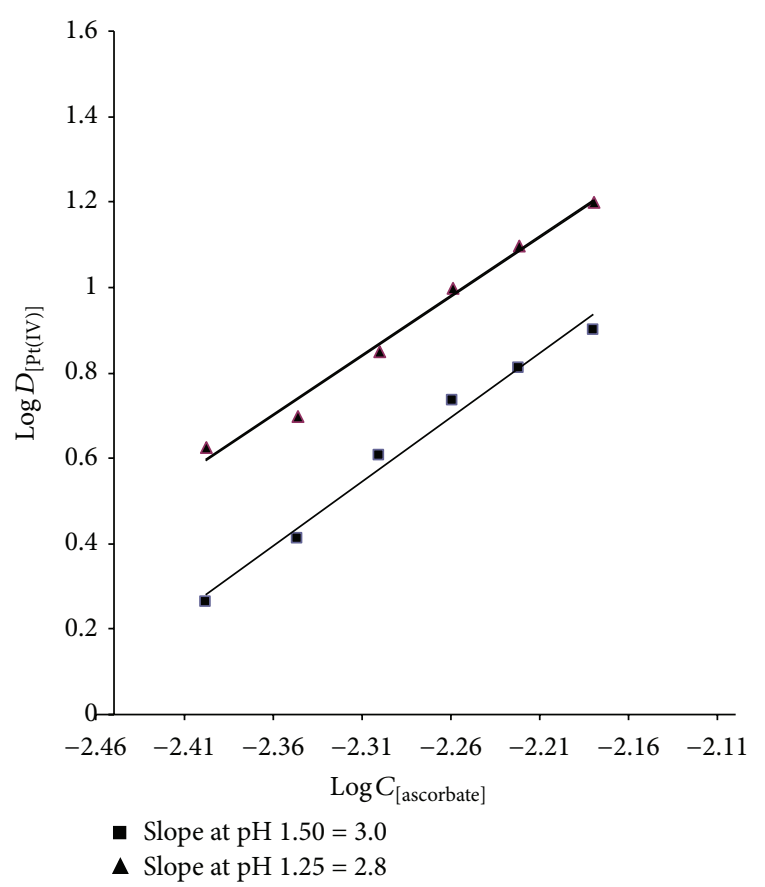

FIgURE 4: Log-log plot of distribution ratio $D_{[\mathrm{Pt}(\mathrm{IV})]}$ versus $\log C_{\text {[ascorbate] }}$ at fixed n-octylaniline concentration.

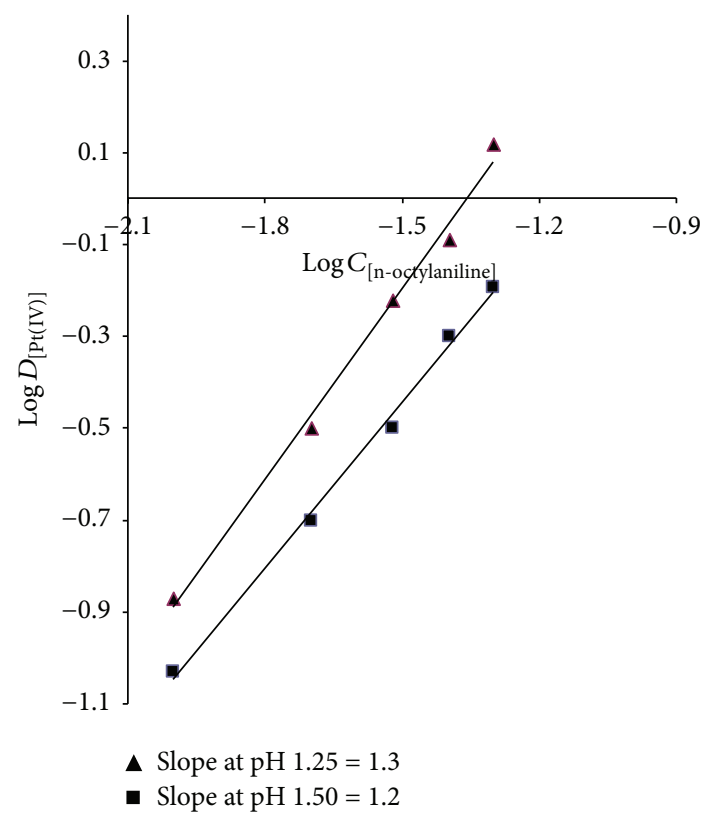

FIgURE 5: Log-log plot of distribution ratio $D_{[\mathrm{Pt}(\mathrm{IV})]}$ versus $\log C_{[\mathrm{n} \text {-octylaniline] }}$ at fixed ascorbate concentration.

association complex with the probable composition $1: 3: 1$ (metal: acid: extractant).

In the extraction of platinum(IV) with ascorbate medium, first platinum(IV) was reduced to platinum(II) [46]; then it was converted into platinum(II) ascorbate as an anion and interacted with $\left[\mathrm{CH}_{3}\left(\mathrm{CH}_{2}\right)_{7} \mathrm{C}_{6} \mathrm{H}_{4} \mathrm{NH}_{3}\right]^{+}$(org) . Hence the
TABLE 3: Extraction of platinum(IV) as a function of aqueous to organic volume ratio. $(\mathrm{Pt}(\mathrm{IV})=150 \mu \mathrm{g}, \mathrm{Aq}: \mathrm{Org}=2.5: 1, \mathrm{pH}=0.50$, ascorbic acid $=0.01 \mathrm{M}$, equilibrium time $=3 \mathrm{~min}$, and n-octylaniline $=0.1 \mathrm{M}$ in toluene).

\begin{tabular}{lcc}
\hline $\begin{array}{l}\text { Aqueous to organic } \\
\text { volume ratio }\end{array}$ & $\begin{array}{c}\text { Percentage } \\
\text { extraction, }(\% E)\end{array}$ & $\begin{array}{c}\text { Distribution ratio, } \\
(D)\end{array}$ \\
\hline $10: 10$ & 100 & $\infty$ \\
$20: 10$ & 100 & $\infty$ \\
$25: 10^{*}$ & 100 & $\infty$ \\
$30: 10$ & 100 & $\infty$ \\
$35: 10$ & 100 & $\infty$ \\
$40: 10$ & 100 & $\infty$ \\
$50: 10$ & 94.6 & 43.79 \\
$75: 10$ & 74.1 & 7.15 \\
$100: 10$ & 59.4 & 3.65 \\
\hline
\end{tabular}

${ }^{*}$ Recommended for general extraction procedure.

TABLE 4: Metal loading capacity of $n$-octylaniline. $(\mathrm{pH}=0.50$, Aq: Org $=2.5: 1$, ascorbic acid $=0.01 \mathrm{M}$, equilibrium time $=3 \mathrm{~min}$, and $\mathrm{n}$-octylaniline $=0.1 \mathrm{M}$ in toluene).

\begin{tabular}{lcc}
\hline Pt $(\mathrm{IV}),(\mu \mathrm{g})$ & Percentage extraction, $(\% E)$ & Distribution ratio, $(D)$ \\
\hline 50 & 100 & $\infty$ \\
100 & 100 & $\infty$ \\
$150^{*}$ & 100 & $\infty$ \\
200 & 100 & $\infty$ \\
300 & 100 & $\infty$ \\
400 & 100 & $\infty$ \\
600 & 100 & $\infty$ \\
800 & 100 & $\infty$ \\
1000 & 100 & $\infty$ \\
1500 & 100 & $\infty$ \\
2000 & 81.5 & 11.01 \\
2500 & 39.5 & 1.63 \\
\hline
\end{tabular}

${ }^{*}$ Recommended for general extraction procedure.

TABLE 5: Effect of foreign ions on the extraction of platinum(IV). $(\mathrm{Pt}(\mathrm{IV})=150 \mu \mathrm{g}, \mathrm{Aq}:$ Org $=2.5: 1, \mathrm{pH}=0.50$, ascorbic acid $=0.01 \mathrm{M}$, equilibrium time $=3 \mathrm{~min}$, and $\mathrm{n}$-octylaniline $=0.1 \mathrm{M}$ in toluene) .

\begin{tabular}{ll}
\hline Tolerance limit, mg & Foreign ion added \\
\hline 25 & Tartrate, $\mathrm{Mg}(\mathrm{II})$ \\
15 & $\mathrm{Fe}(\mathrm{III}), \mathrm{Zn}(\mathrm{II}), \mathrm{Mo}(\mathrm{VI}), \mathrm{Se}(\mathrm{IV}), \mathrm{Ba}(\mathrm{II})$, \\
& $\mathrm{Ce}(\mathrm{IV})$, oxalate, citrate, bromide \\
10 & $\mathrm{Ni}(\mathrm{II}), \mathrm{Co}(\mathrm{II}), \mathrm{U}(\mathrm{VI}), \mathrm{Hg}(\mathrm{II})$ \\
5 & $\mathrm{Cu}(\mathrm{II}), \mathrm{Pb}(\mathrm{II}), \mathrm{Cr}(\mathrm{VI}), \mathrm{Cr}(\mathrm{III}), \mathrm{Bi}(\mathrm{III})$, \\
& $\mathrm{Te}(\mathrm{IV}), \mathrm{Cd}(\mathrm{II}), \mathrm{EDTA}$, nitrate \\
2 & $\mathrm{Tl}(\mathrm{I}), \mathrm{Ca}(\mathrm{II}), \mathrm{Al}(\mathrm{III}), \mathrm{Cr}(\mathrm{III}), \mathrm{Cd}(\mathrm{II})$ \\
1 & $\mathrm{Ag}(\mathrm{I}), \mathrm{Os}(\mathrm{VIII}), \mathrm{Ru}(\mathrm{III})$ \\
0.5 & $\mathrm{Rh}(\mathrm{III})^{\mathrm{a}}, \mathrm{Pd}(\mathrm{II})^{\mathrm{a}}, \mathrm{Ir}(\mathrm{III}), \mathrm{Au}(\mathrm{III})$ \\
\hline
\end{tabular}

${ }^{\mathrm{a}}$ Masked with $20 \mathrm{mg}$ tartrate.

probable extracted species in toluene is $\left[\mathrm{CH}_{3}\left(\mathrm{CH}_{2}\right)_{7} \mathrm{C}_{6} \mathrm{H}_{4}\right.$ $\left.\mathrm{NH}_{3} \cdot \mathrm{Pt}\left(\mathrm{C}_{6} \mathrm{H}_{7} \mathrm{O}_{6}\right)_{3}^{-}\right]_{(\text {org })}$. 
TABLE 6: Separation of platinum(IV) from binary mixtures.

\begin{tabular}{|c|c|c|c|c|}
\hline Amount of metal ion, $(\mu \mathrm{g})$ & Mass taken, $(\mu \mathrm{g})$ & Average (\%) recovery ${ }^{*}$ & Chromogenic ligand & Reference no. \\
\hline $\mathrm{Pt}(\mathrm{IV})$ & 150 & 99.5 & \multirow{2}{*}{ Stannous chloride-hydrobromic acid } & \multirow{2}{*}[44]{} \\
\hline $\operatorname{Ir}(\mathrm{III})$ & 100 & 99.4 & & \\
\hline $\mathrm{Pt}(\mathrm{IV})$ & 150 & 99.7 & \multirow{2}{*}{ Stannous chloride-KI } & \multirow{2}{*}[44]{} \\
\hline $\operatorname{Rh}(\mathrm{III})^{\mathrm{a}}$ & 300 & 99.2 & & \\
\hline $\mathrm{Pt}(\mathrm{IV})$ & 150 & 99.8 & \multirow{2}{*}{$4^{\prime}$-ChloroPTPT } & \multirow{2}{*}[47]{} \\
\hline $\operatorname{Pd}(\mathrm{II})^{\mathrm{a}}$ & 200 & 99.4 & & \\
\hline $\mathrm{Pt}(\mathrm{IV})$ & 150 & 99.2 & \multirow{2}{*}{$4^{\prime}$-ChloroPTPT } & \multirow{2}{*}[47]{} \\
\hline $\mathrm{Ru}(\mathrm{III})$ & 200 & 98.9 & & \\
\hline $\mathrm{Pt}(\mathrm{IV})$ & 150 & 99.8 & \multirow{2}{*}{$\mathrm{SnCl}_{2}$} & \multirow{2}{*}[44]{} \\
\hline $\mathrm{Au}(\mathrm{III})$ & 200 & 99.1 & & \\
\hline $\operatorname{Pt}(\mathrm{IV})$ & 150 & 99.7 & \multirow{2}{*}{$4^{\prime}$-ChloroPTPT } & \multirow{2}{*}[48]{} \\
\hline $\mathrm{Se}(\mathrm{IV})$ & 200 & 99.0 & & \\
\hline $\mathrm{Pt}(\mathrm{IV})$ & 150 & 99.8 & \multirow{2}{*}{$4^{\prime}$-ChloroPTPT } & \multirow{2}{*}[49]{} \\
\hline $\mathrm{Te}(\mathrm{IV})$ & 200 & 98.9 & & \\
\hline $\mathrm{Pt}(\mathrm{IV})$ & 150 & 99.4 & \multirow{2}{*}{ Thiourea } & \multirow{2}{*}[44]{} \\
\hline Os(VIII) & 200 & 99.0 & & \\
\hline $\operatorname{Pt}(\mathrm{IV})$ & 150 & 99.4 & \multirow{2}{*}{ Thiocyanate } & \multirow{2}{*}[44]{} \\
\hline $\mathrm{Fe}(\mathrm{III})$ & 500 & 98.7 & & \\
\hline $\operatorname{Pt}(\mathrm{IV})$ & 150 & 99.0 & \multirow{2}{*}{$4^{\prime}$-ChloroPTPT } & \multirow{2}{*}[50]{} \\
\hline $\mathrm{Cu}(\mathrm{II})$ & 1000 & 98.6 & & \\
\hline $\operatorname{Pt}(\mathrm{IV})$ & 150 & 99.0 & \multirow{2}{*}{ DMG } & \multirow{2}{*}[46]{} \\
\hline $\mathrm{Ni}(\mathrm{II})$ & 1000 & 97.9 & & \\
\hline $\mathrm{Pt}(\mathrm{IV})$ & 150 & 99.9 & \multirow{2}{*}{ Thiocyanate } & \multirow{2}{*}[44]{} \\
\hline $\mathrm{Co}(\mathrm{II})$ & 500 & 97.8 & & \\
\hline
\end{tabular}

${ }^{\mathrm{a}}$ Masked with $20 \mathrm{mg}$ tartrate.

* Average of five determinations.

3.10. Effect of Various Foreign Ions on Percentage Extraction. The effect of various diverse ions was tested, when platinum(IV) was extracted with n-octylaniline in toluene. The tolerance limit was set as the amount of foreign ion causing a change $\pm 2 \%$ error in the recovery of platinum(IV). It was observed that the method is free from interference from a large number of cations and anions (Table 5).

Species like iodide, thiocyanate, thiourea, palladium(II), and rhodium(III) interfere in the extraction of platinum(IV). However, the interference of Pd(II) and Rh(III) was eliminated by masking with tartrate.

\section{Applications}

4.1. Separation and Determination of Platinum(IV) from Binary Mixture. The separation of Pt (IV) from some commonly associated metal ions like $\mathrm{Ru}(\mathrm{III}), \mathrm{Au}(\mathrm{III}), \mathrm{Os}(\mathrm{VIII})$, $\mathrm{Se}(\mathrm{IV}), \mathrm{Te}(\mathrm{IV}), \mathrm{Fe}(\mathrm{III}), \mathrm{Co}(\mathrm{II}), \mathrm{Ni}(\mathrm{II})$, and $\mathrm{Cu}(\mathrm{II})$ using noctylaniline was achieved by taking advantage of the difference in the extraction conditions of metal such as $\mathrm{pH}$ of the aqueous phase, reagent concentration, and use of masking agent (Table 6). All the added metal ions remained quantitatively in aqueous phase from which they are determined spectrophotometrically by standard methods [45, 47-51].

$\mathrm{Rh}(\mathrm{III})$ and $\mathrm{Pd}(\mathrm{II})$ interfere in the extraction of $\mathrm{Pt}(\mathrm{IV})$. $\mathrm{Rh}$ (III) and $\mathrm{Pd}(\mathrm{II})$ were separated from $\mathrm{Pt}(\mathrm{IV})$ by masking with $20 \mathrm{mg}$ tartrate.
4.2. Analysis of Platinum(IV) in Catalysts Sample. Platinum(IV) activated alumina (0.1 g) was dissolved in $20 \mathrm{~mL}$ aqua regia. The solution was evaporated to moist dryness. Two $5 \mathrm{~mL}$ portions of hydrochloric acid were added and evaporated till all the nitric acid was removed. The residue was extracted in $1 \mathrm{M}$ hydrochloric acid. The solution was filtered, and the filtrate was diluted to $100 \mathrm{~mL}$. An aliquot of this diluted solution was analyzed for platinum(IV) content by the proposed method. It was found that there is a good agreement with the certified value (Table 7 ).

\subsection{Analysis of Platinum(IV) from Real Samples}

4.3.1. Cytoplatin (Cisplatin Injection). The method permits the separation and determination of platinum(IV) from drug sample, cytoplatin (cisplatin injection), and platinumrhodium thermocouple wire. Cytoplatin (cisplatin injection) is an antineoplastic agent with the biochemical properties similar to those of bifunctional alkylating agents, although, not yet clearly established, its cytotoxic actions and antitumor activity are consistent with the hypothesis that major cytotoxic target of cisplatin in DNA. The drug covalently binds to DNA bases and disrupts DNA functions. Cytoplatin appears to enter cells by diffusion.

Cytoplatin is a sterile solution of cisplatin I.P. $1.0 \mathrm{mg} / \mathrm{mL}$, sodium chloride I.P. $9 \mathrm{mg} / \mathrm{mL}$ in water for injection I.P. Cytoplatin containing cisplatin which is a heavy metal platinum 
TABLE 7: Determination of platinum(IV) from catalysts.

\begin{tabular}{|c|c|c|c|c|c|}
\hline Sr. no. & Alloy & $\begin{array}{c}\text { Platinum(IV) taken, } \\
\mu \mathrm{g}\end{array}$ & $\begin{array}{c}\text { Platinum(IV) } \\
{ }^{*} \text { Found by method in } \mu \mathrm{g}\end{array}$ & Average, $\%$ recovery & RSD, \% \\
\hline (1) & $\begin{array}{c}\mathrm{Pt}-\mathrm{Pd}^{\mathrm{a}}-\mathrm{Rh}^{\mathrm{a}} \\
\text { catalyst on alumina }\end{array}$ & 150 & 149.2 & 99.4 & 0.6 \\
\hline (2) & $\begin{array}{c}\mathrm{Pt}-\mathrm{Rh}^{\mathrm{a}} \\
\text { catalyst on alumina }\end{array}$ & 150 & 149.5 & 99.6 & 0.4 \\
\hline (3) & $\begin{array}{c}\text { Pt-Pd }{ }^{\mathrm{a}} \\
\text { catalyst on alumina }\end{array}$ & 150 & 149.8 & 99.8 & 0.2 \\
\hline (4) & $\begin{array}{c}\mathrm{Pt} \\
\text { catalyst on alumina }\end{array}$ & 300 & 299.5 & 99.8 & 0.2 \\
\hline
\end{tabular}

${ }^{a}$ Masked with $20 \mathrm{mg}$ tartrate.

*Average of five determinations.

Composition of synthetic mixtures in percentage

(1) Pt, 0.03-0.25; Rh, 0.005-0.03.

(2) Pt, $0.03-0.15 ; \mathrm{Pd}, 0.02-0.12$.

(3) Pt, $0.03-0.20$; Pd, 0.03-0.150; Rh, 0.015-0.05.

(4) Pt, $0.3-0.8$.

TABLE 8: Analysis of platinum(IV) from real samples.

\begin{tabular}{|c|c|c|c|c|}
\hline Sample & Manufacturer & $\begin{array}{c}\text { Amount } \\
\text { taken }\end{array}$ & $\begin{array}{l}\text { Amount of } \\
\text { platinum(IV) } \\
\text { found }\end{array}$ & RSD, \% \\
\hline Cytoplatin (cisplatin injection) & Cipla, Goa & $200 \mu \mathrm{g} / \mathrm{mL}$ & $198.6 \mu \mathrm{g} / \mathrm{mL}$ & 0.7 \\
\hline Platinum-rhodium ${ }^{\text {a }}$ thermocouple wire $(\mathrm{Pt}, 87 ; \mathrm{Rh}, 13)$ & $\begin{array}{c}\text { Ruia Resistance } \\
\text { Wire Pvt. Ltd., Mumbai }\end{array}$ & $87 \%$ & $86.4 \%$ & 0.6 \\
\hline
\end{tabular}

${ }^{\mathrm{a}}$ Masked with $20 \mathrm{mg}$ tartrate.

coordination complex containing a central atom of platinum is surrounded by two entities each of chloride ions and two ammonia molecules in cis geometry. It has a melting point of $207^{\circ} \mathrm{C}$.

The empirical formula of the active compound is $\mathrm{PtCl}_{2} \mathrm{H}_{6} \mathrm{~N}_{2}$ with a molecular weight of 300.1 .

A known volume $(10 \mathrm{~mL})$ of cisplatin solution was digested in perchloric acid/nitric acid $(10: 1)$ and evaporated to dryness until organic matter was removed. The obtained residue was dissolved in concentrated hydrochloric acid and diluted with water to $10 \mathrm{~mL}$ in a standard volumetric flask.

An aliquot of the sample solution was taken, and platinum(IV) was determined using the recommended procedure (Table 8).

4.3.2. Thermocouple Wire. A known weight (0.100) of thermocouple wire was preliminary fused with zinc powder, and the melt was cooled and dissolved in hydrochloric acid. The black powder that remained was treated with $5 \mathrm{~mL}$ aqua regia. After the reaction was over the whole solution was heated with two $5 \mathrm{~mL}$ portions of concentrated hydrochloric acid until complete removal of oxides of nitrogen and diluted with distilled water to $10 \mathrm{~mL}$ in standard volumetric flask.

An aliquot of sample solution was taken, and platinum(IV) was determined using the procedure described earlier. The results of the analysis are given in Table 8 .

\section{Conclusion}

(i) Quantitative extraction of platinum(IV) was achieved in $3 \mathrm{~min}$ with $0.1 \mathrm{M} \mathrm{n}$-octylaniline in toluene at $\mathrm{pH}$ 0.50 .

(ii) Extraction reaction occurred through anion-exchange mechanism.

(iii) Developed method is efficient for quantitative separation of platinum(IV) in presence of various interfering cations and anions.

(iv) The proposed extractive separation method is simple, rapid, selective reproducible, and suitable for separation and determination of platinum(IV) from associated metal ions, real samples, and synthetic mixtures.

\section{Acknowledgments}

The authors are thankful to Sung. H. Han, Professor, Inorganic Nano-Materials Research Laboratory, Department of Chemistry, Hanyang University, Seoul, Republic of Korea for constant encouragement. They are thankful to UGC-SAP and DST-FIST, Department of Chemistry, Shivaji University, Kolhapur. 


\section{References}

[1] J.-Y. Lee, J. R. Kumar, J.-S. Kim, H.-K. Park, and H.-S. Yoon, "Liquid-liquid extraction/separation of platinum(IV) and rhodium(III) from acidic chloride solutions using tri-isooctylamine," Journal of Hazardous Materials, vol. 168, no. 1, pp. 424-429, 2009.

[2] B. Swain, J. Jeong, S.-K. Kim, and J.-C. Lee, "Separation of platinum and palladium from chloride solution by solvent extraction using Alamine 300," Hydrometallurgy, vol. 104, no. 1, pp. 1-7, 2010.

[3] C. R. M. Rao and G. S. Reddi, "Platinum group metals (PGM); occurrence, use and recent trends in their determination," Trends in Analytical Chemistry, vol. 19, no. 9, pp. 565-586, 2000.

[4] K. Fujiwara, A. Ramesh, T. Maki, H. Hasegawa, and K. Ueda, "Adsorption of platinum (IV), palladium (II) and gold (III) from aqueous solutions onto l-lysine modified crosslinked chitosan resin," Journal of Hazardous Materials, vol. 146, no. 1-2, pp. 3950, 2007.

[5] E. E. Rakoskii, N. V. Shveddova, and L. D. Berliner, "Solvent extraction of the platinum metals in the presence of stannous chloride and di-o-tolylthiourea," Journal of Analytical chemistry of the USSR, vol. 29, p. 1933, 1974.

[6] S. J. Al-Bazi and A. Chow, "Polyurethane foam for the extraction of rhodium and its separation from iridium," Talanta, vol. 31, no. 6, pp. 431-435, 1984.

[7] A. Diamantatos and A. A. Verbeek, "Method for the separation of platinum, palladium, rhodium, iridium and gold by solvent extraction," Analytica Chimica Acta, vol. 91, no. 2, pp. 287-294, 1977.

[8] Y. A. Zolotov, O. M. Petrukhin, V. N. Schevehenko, V. V. Duniva, and E. G. Rukhadze, "Solvent extraction of noble metals with derivatives of thiourea," Analytica Chimica Acta, vol. 100, pp. 613-618, 1978.

[9] M. Mojski, "Extraction of platinum metals from hydrochloric acid medium with triphenylphosphine solution in 1,2dichloroethane," Talanta, vol. 27, no. 1, pp. 7-10, 1980.

[10] M. Cox, "Solvent extraction in hydrometallurgy", in Principle and Practices of Solvent Extraction, J. Rydberg, C. Musikas, and G. R. Choppin, Eds., vol. 10, pp. 357-412, Marcal Dekker, New York, NY, USA, 1992.

[11] V. V. Belova and A. A. Vasileva, "The extraction of platinum from sulfate solutions with p-octylaniline," Izvestiya Sibirskogo Otdeleniya Akademii Nauk SSSR, Seriya Khimicheskikh Nauk, vol. 3, p. $58,1986$.

[12] K. K. Turaev, A. K. Turdikulov, and G. Z. Mukimova, "Extraction of sulfate complexes of platinum metals with binary extractants," Ozbekiston Kimyo Jurnali, vol. 3, p. 19, 2002.

[13] S. S. Kolekar and M. A. Anuse, "Selective liquid-liquid extraction of platinum(IV) from ascorbate media by N-n-octylaniline: its separation from associated elements and real samples," Separation Science and Technology, vol. 38, no. 11, pp. 2597-2618, 2003.

[14] J. Fu, S. Nakamura, and K. Akiba, "Extraction of platinum(IV) with trioctylamine and its application to liquid membrane transport," Separation Science and Technology, vol. 30, no. 4, pp. 609-619, 1995.

[15] J. Fu, S. Nakamura, and K. Akiba, "Separation of precious metals through a trioctylamine liquid membrane," Separation Science and Technology, vol. 32, no. 8, pp. 1433-1445, 1997.

[16] H. Yoshizawa, K. Shiomori, S. Yamada et al., "Solvent extraction of platinum(IV) from aqueous acidic chloride media with tri-n-octylamine in toluene," Solvent Extraction Research and Development, vol. 1997, no. 4, pp. 157-166, 1997.

[17] T. Sadyrbaeva, "Membrane extraction of platinum(IV) by trin-octylamine in the presence of nickel(II)," Rigas Tehniskas Universitates Zinatniskie Raksti, Sderija 1: Materialzinatne Un Lietiska Kimija, vol. 15, p. 126, 2007.

[18] K. Shiomori, K. Fujikubo, Y. Kawano, Y. Hatate, Y. Kitamura, and H. Yoshizawa, "Extraction and separation of precious metals by a column packed with divinylbenzene homopolymeric microcapsule containing tri-n-octylamine," Separation Science and Technology, vol. 39, no. 7, pp. 1645-1662, 2004.

[19] M. A. Barakat and M. H. H. Mahmoud, "Recovery of platinum from spent catalyst," Hydrometallurgy, vol. 72, no. 3-4, pp. 179$184,2004$.

[20] M. S. Lee, J. Y. Lee, J. R. Kumar, J. S. Kim, and J. S. Sohn, "Solvent extraction of $\mathrm{PtCl} 4$ from hydrochloric acid solution with alamine336," Materials Transactions, vol. 49, no. 12, pp. 2823-2828, 2008.

[21] P. P. Sun and M. S. Lee, "Separation of Pt(IV) and Pd(II) from the loaded Alamine 336 by stripping," Hydrometallurgy, vol. 109, no. 1-2, pp. 181-184, 2011.

[22] J.-Y. Lee, R. Kumar, J. S. Kim, and J.-S. Sohn, "Solvent extraction of Pt(IV) from acidic chloride solutions using alamine 336," in Proceedings of the Global Symposium on Recycling, Waste Treatment and Clean Technology (REWAS '08), pp. 1755-1760, Cancun, Mexico, October 2008.

[23] P. P. Sun and M. S. Lee, "Separation of Pt from hydrochloric acid leaching solution of spent catalysts by solvent extraction and ion exchange," Hydrometallurgy, vol. 110, no. 1-4, pp. 91-98, 2011.

[24] B. Swain, J. Jeong, S.-K. Kim, and J.-C. Lee, "Separation of platinum and palladium from chloride solution by solvent extraction using Alamine 300," Hydrometallurgy, vol. 104, no. 1, pp. 1-7, 2010.

[25] V. V. Belova, A. I. Khol'Kin, and T. I. Zhidkova, "Extraction of platinum-group metals from chloride solutions by salts of quaternary ammonium bases and binary extractants," Theoretical Foundations of Chemical Engineering, vol. 41, no. 5, pp. 743-751, 2007.

[26] H. Watanabe, A. Kakui, and K. Nagao, "Extraction of platinum(IV) from hydrochloric acid solutions by dihexylsulfide containing micro amount of high molecular-weight amine under irradiation of light," Shigen to Sozai, vol. 116, p. 291, 2000.

[27] S. Katsuta, Y. Yoshimoto, M. Okai, Y. Takeda, and K. Bessho, "Selective extraction of palladium and platinum from hydrochloric acid solutions by trioctylammonium-based mixed ionic liquids," Industrial and Engineering Chemistry Research, vol. 50, no. 22, pp. 12735-12740, 2011.

[28] W. P. Singh, "Extraction of platinum-group metals with diquaternary ammonium salts," US Patents Published Application, 2004.

[29] M. Grote, U. Hüppe, and A. Kettrup, "Solvent extraction of noble metals by formazans-I. Comparative study on the extractability of $\mathrm{Pt}(\mathrm{IV}), \mathrm{Pd}(\mathrm{II})$ and $\mathrm{Ag}(\mathrm{I})$ by formazans combined with a liquid anion-exchanger," Talanta, vol. 31, no. 10, pp. 755-762, 1984.

[30] D. Wenjun, R. Qingxin, and C. Ruona, "Extraction of thiocyanate complexes of platinum group metals ions by MIBK," Guijinshu, vol. 19, p. 20, 1998.

[31] A. Warshawsky, "Separation of the rare platinum group elements (rhodium, iridium, ruthenium, osmium) by extraction with solvating $\pi$-donor ligands and polymers in the thiocyanate 
system," Separation and Purification Methods, vol. 12, no. 2, pp. 119-141, 1983.

[32] T. I. Zhidkova, V. V. Belova, Y. Y. Brenno, L. L. Zhidkov, and A. I. Khol'Kin, "Palladium extraction by a cyanex 301-based binary extractant from chloride solutions," Russian Journal of Inorganic Chemistry, vol. 54, no. 9, pp. 1502-1506, 2009.

[33] R. A. Khisamutdinov, S. O. Bondareva, Y. I. Murinov, and I. P. Baikova, "Extraction of palladium(II), platinum(II), and platinum(IV) by bisacylated diethylenetriamine from hydrochloric acid solutions," Russian Journal of Inorganic Chemistry, vol. 53, no. 3, pp. 462-469, 2008.

[34] T. Ogata, K. Takeshita, G. A. Fugate, and A. Mori, "Extraction of soft metals from acidic media with nitrogen-donor ligand TPEN and its analogs," Separation Science and Technology, vol. 43, no. 9-10, pp. 2630-2640, 2008.

[35] Q. Gaofei, Z. Ying, L. Qin, J. Wenwei, W. Jide, and Y. Qin, "Process and application of recovering platinum from used liquid-phase catalysts by solvent extraction with thiourea," Yingyong Huaxue, vol. 28, p. 1337, 2011.

[36] K.-H. König, M. Schuster, B. Steinbrech, G. Schneeweis, and R. Schlodder, "N,N-Dialkyl-N'-benzoylthioureas as reagents for selective extractions to separate and enrich platinum-group metals," Fresenius' Zeitschrift für Analytische Chemie, vol. 321, no. 5, pp. 457-460, 1985.

[37] P. Vest, M. Schuster, and K.-H. König, "Influence of tin(II) chloride on the solvent extraction of platinum group metals with N,N-di-n-hexyl-N'-benzoylthiourea," Fresenius' Journal of Analytical Chemistry, vol. 339, no. 3, pp. 142-144, 1991.

[38] M. Merdivan, R. S. Aygun, and N. Külcü, "Solvent extraction of platinum group metals with N,N-diethyl-N'-benzoylthiourea," Annali di Chimica, vol. 90, no. 5-6, pp. 407-412, 2000.

[39] Y. Terada, A. Harada, K. Saito, S. Murakami, and A. Muromatsu, "Solvent extraction of platinum(II) with 1,3-dimethyl-2thiourea and bromocresol green," Bunseki Kagaku, vol. 52, no. 9, pp. 725-729, 2003.

[40] A. Uheida, Y. Zhang, and M. Muhammed, "Extraction of platinum(IV) with nonylthiourea dissolved in chloroform from hydrochloric acid media," Solvent Extraction and Ion Exchange, vol. 21, no. 6, pp. 827-840, 2003.

[41] A. Uheida, Y. Zhang, and M. Muhammed, "Thermodynamic modeling of extraction equilibria of platinum and palladium with nonylthiourea from hydrochloric acid media," Separation Science and Technology, vol. 39, no. 15, pp. 3665-3677, 2004.

[42] M. Iwakuma, S. Nakamura, and Y. Baba, "Synthesis of a thiourea derivative containing a sulfur atom and extraction equilibrium of platinum(IV) from hydrochloric acid," Solvent Extraction Research and Development, vol. 11, pp. 103-110, 2004.

[43] T. I. Tikhomirova, V. I. Fadeeva, G. V. Kudryavtsev et al., "Sorption of noble-metal ions on silica with chemically bonded nitrogen-containing ligands," Talanta, vol. 38, no. 3, pp. 267274, 1991.

[44] C. Pohlandt, "The extraction of noble metals with noctylaniline," Talanta, vol. 26, no. 3, pp. 199-206, 1979.

[45] E. B. Sandell, Colorimetric Determination of Traces of Metals, Interscience, New York, NY, USA, 3rd edition, 1965.

[46] H. Li, J. Ding, and J. Wu, "Physical properties and application performance of platinum-palladium-rhodium alloys modified with cerium," Guijinshu, vol. 18, p. 42, 1997.

[47] Z. Marczenko, Spectophotometric Determination of Elements, Ellis Horwood Limited, Chichester, UK, 1976.
[48] M. A. Anuse and M. B. Chavan, "Studies on extraction separation of platinum metals and gold(III) with pyrimidinethiol: spectrophotometric determination of palladium(II), osmium(VIII) and ruthenium(III)," Chemia Analityczna, vol. 29, p. 409, 1984.

[49] G. B. Kolekar and M. A. Anuse, "Extractive spectrophotometric determination of selenium(IV) using 1-( $4^{\prime}$-bromophenyl)4,4,6-trimethyl-1,4- dihydropyrimidine 2-thiol," Research Journal of Chemistry and Environment, vol. 2, p. 9, 1998.

[50] G. B. Kolekar and M. A. Anuse, "Extraction, separation, and spectrophotometric determination of tellurium(IV) with 1-(4'bromophenyl)-4,4,6-trimethyl-1,4-dihydropyrimidine 2-thiol," Bulletin of the Chemical Society of Japan, vol. 71, no. 4, pp. 859866, 1998.

[51] M. A. Anuse, S. R. Kuchekar, and M. B. Chavan, "1-(4'Chlorophenyl)-4, 4, 6-trimethyl-1, 4-dihydropyrimidine 2-thiol as an effective reagent for the spectrophotometric determination of copper after synergic extraction," Indian Journal of Chemistry, vol. 25, p. 1041, 1986. 

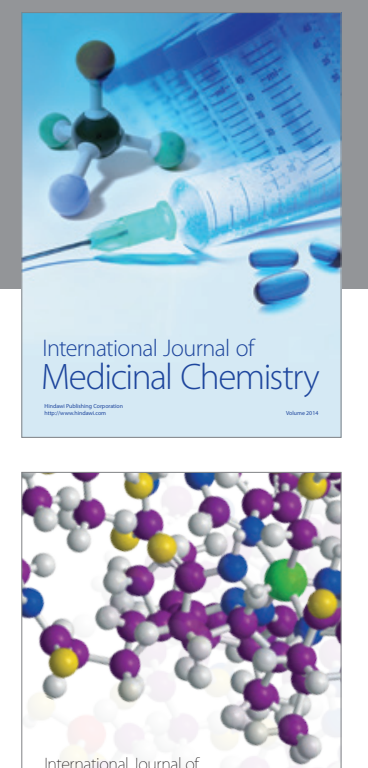

\section{Carbohydrate} Chemistry

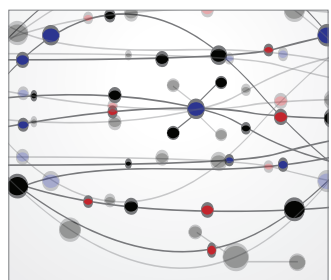

The Scientific World Journal
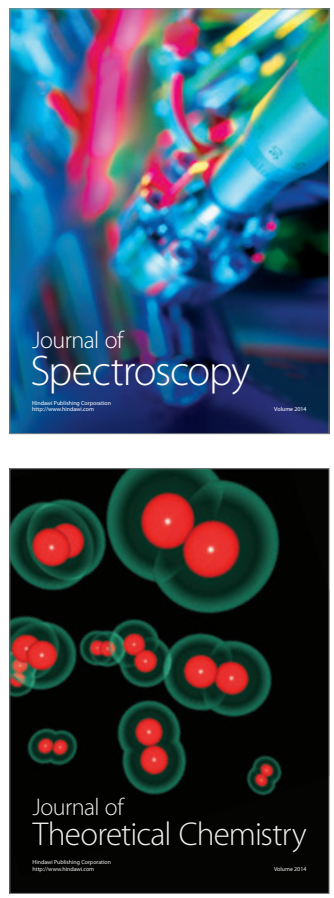
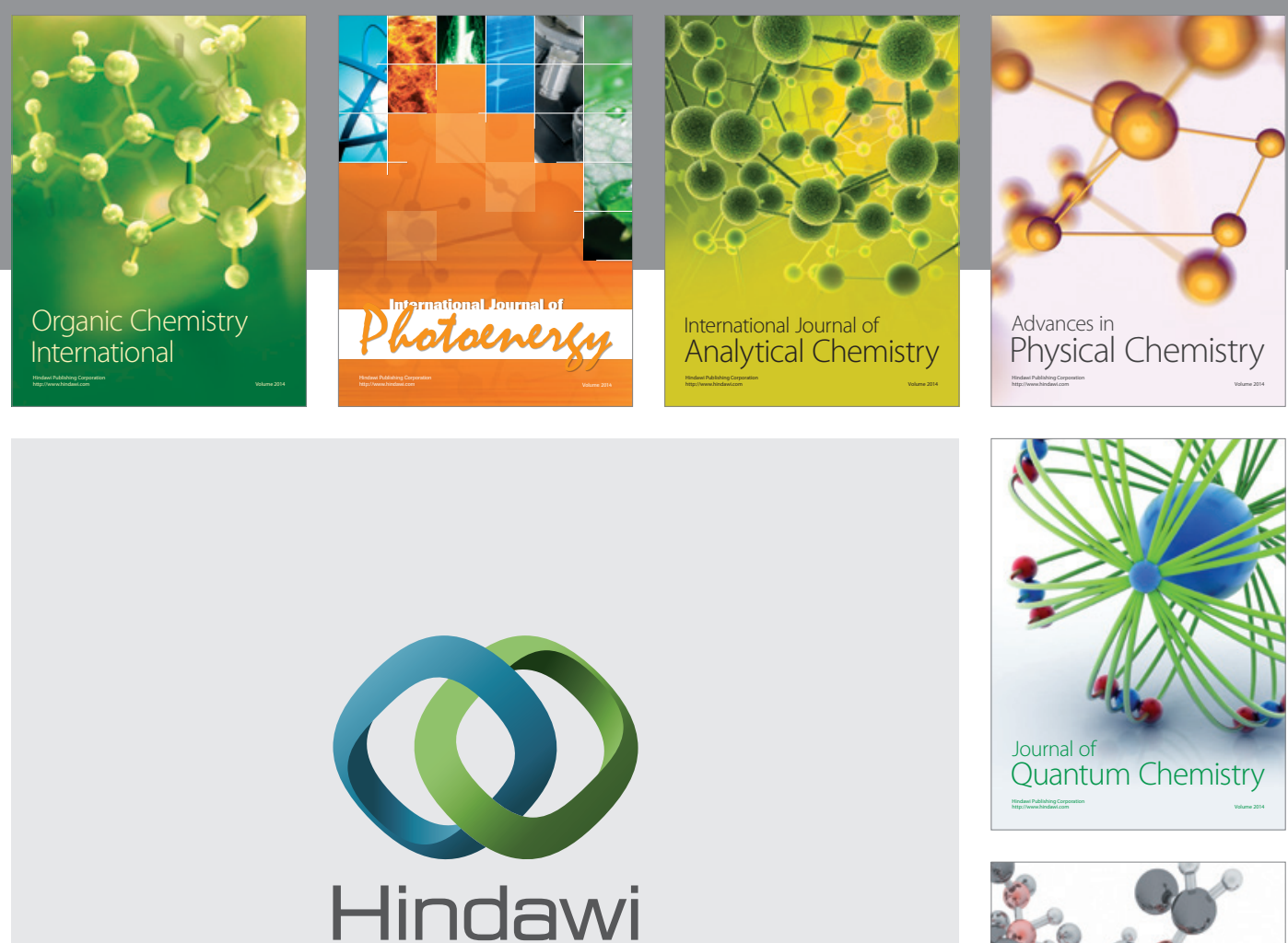

Submit your manuscripts at

http://www.hindawi.com

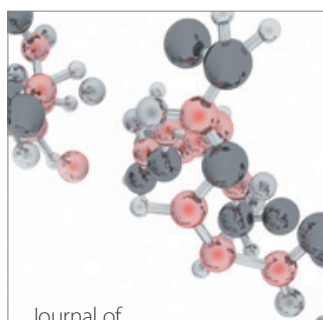

Analytical Methods

in Chemistry

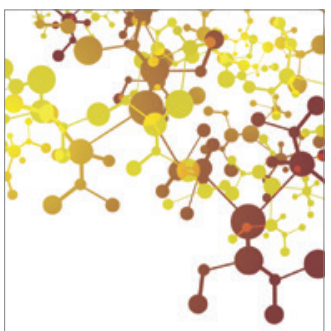

Journal of

Applied Chemistry

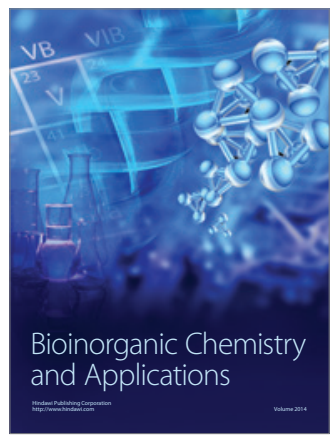

Inorganic Chemistry
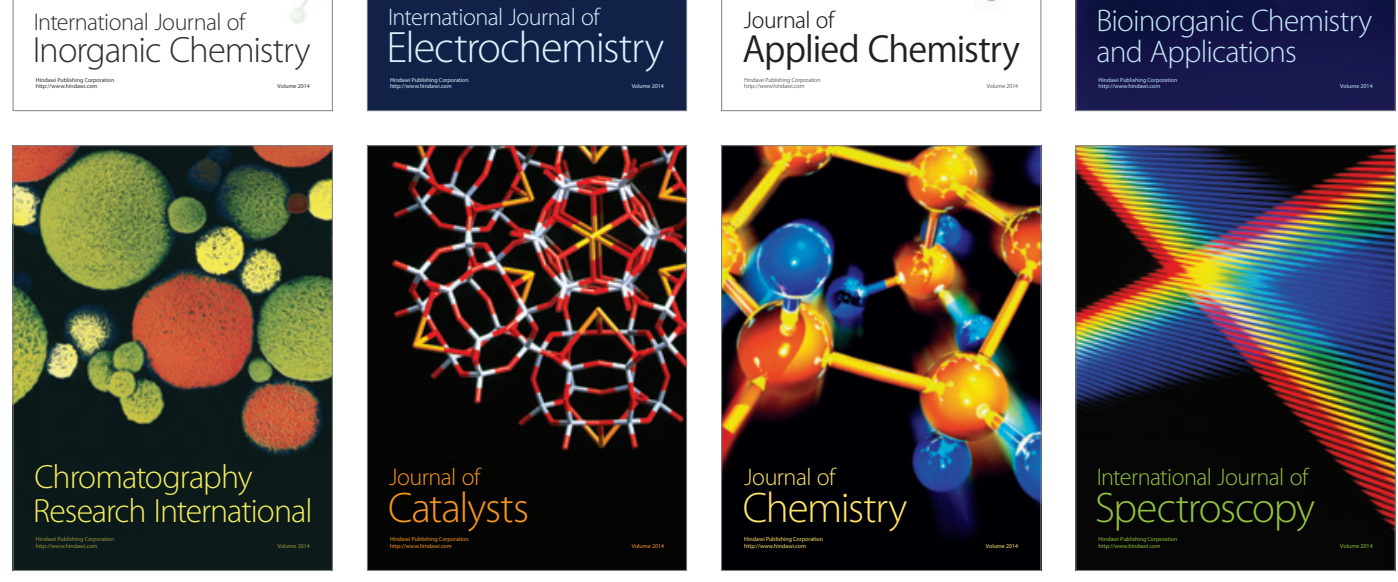